\title{
Influence Of Crushed Stone Aggregates From The Rodeb Distribution Center In The Mechanical Properties Of The Concretes Employed For The Construction Of The Tocancipá Free Trade Zone
}

Influencia de agregados de piedra aplicada del centro de distribución de Rodeb en las propiedades mecánicas de los concretos empleados para la construcción

de la zona de libre comercio de Tocancipá

Influência de agregados de pedra aplicada do centro de distribuição

Rodeb nas propriedades mecânicas do concreto utilizado na construção

da zona de livre comércio de Tocancipá

Ferney Oswaldo Peña Rey ${ }^{1}$

Javier Eduardo Becerra Becerra²

Angie Cristina Culma Pirabán ${ }^{3}$

Faindry Julieth Rojas Farfán ${ }^{4}$

Received: January $15^{\text {th }}, 2020$

Accepted: March $20^{\text {th }}, 2020$

Available: May $4^{\text {th }}, 2020$

How to cite this article:

F. O. Peña Rey, J. E. Becerra Becerra, A. C. Culma Pirabán, F. J. Rojas Farfán, “Influence of Crushed Stone Aggregates from The Rodeb Distribution Center in the Mechanical Properties of the Concretes Employed for The Construction of the Tocancipá Free Trade

Zone," Revista Ingeniería Solidaria, vol. 16, no. 2, 2020. doi: https://doi.org/10.16925/2357-6014.2020.02.05

Artículo de investigación. https://doi.org/10.16925/2357-6014.2020.02.05

1 Department of Civil Engineering. Faculty of Engineering. Universidad Santo Tomas.

ORCID: https://orcid.org/0000-0003-1319-2745

Email: ferneypena@usantotomas.edu.co

2 Geologist. Universidad Nacional de Colombia.

ORCID: https://orcid.org/0000-0002-8843-9442

E-mail: javierbecerra@usantotomas.edu.co

3 Department of Civil Engineering. Faculty of Engineering. Universidad Santo Tomas.

ORCID: https://orcid.org/0000-0002-8231-127X

Email: angieculma@usantotomas.edu.co

4 Department of Civil Engineering. Faculty of Engineering. Universidad Santo Tomas.

ORCID: https://orcid.org/0000-0002-1874-9648

E-mail: faindry.rojas@usantotomas.edu.co 


\section{Abstract}

Introduction: This article is a product of the research "The influence of stone aggregates of the Rodeb distribution center on the mechanical properties of the concrete used for the construction of the free trade zone of Tocancipa", developed at the Universidad Santo Tomas and carried out during 2017.

Problem: The quality of stone aggregates can influence the physical-mechanical characteristics of the concrete. For this reason, this research seeks to determine the variation in mechanical properties of the concrete used for the construction of the free zone of Tocancipa, using aggregates from the nearby "Rodeb distribution center", and comparing it with certified quality concrete types.

Objective: Compare the resistance of commercial concrete of 21 and $28 \mathrm{MPa}$, when combined with crushed stone aggregates from the Rodeb distribution center, with aggregates of a nationally recognized establishment in the city of Bogotá.

Methodology: The use of crushed stone aggregates without quality standards, those that guarantee the resistance of commercial concrete, is a problem in the country; with the understanding that the physical properties of stone aggregates affect the physical properties of fresh concrete and hardening strength.

In this study, crushed stone aggregates of the "Rodeb" collection center in Tocancipa, used for the construction of its Free Trade Zone and of technically supported aggregate types in the capital city, will be physically characterized to measure the mechanical variation in of 21 and $28 \mathrm{MPa}$ concrete.

Results: It was found that the "Rodeb collection" aggregates comply with the physical parameters that achieve the expected design resistance, and to a greater degree than the results obtained by the certified quality aggregates.

Conclusion: This project seeks to raise awareness about the variability in the physical and mechanical properties of concrete, according to the characterization of the crushed stone aggregates used.

Originality: It seeks to implement a mix design at the Rodeb collection center for its aggregates.

Limitations: To continue with the investigation, it is necessary to carry out additional tests of physical-chemical characterization to better understand how the texture and shape of aggregates can influence the mechanical properties of concrete. Additionally, it is important to disseminate the results in the Tocancipa community.

Keywords: Crushed stone aggregates, concrete, gradation, strength, the Walker's method.

\section{Resumen}

Introducción: El presente artículo es producto de la investigación "La influencia de los agregados pétreos del acopio Rodeb, en las propiedades mecánicas de los concretos empleados para la construcción de la zona franca de Tocancipa", realizada en la Universidad Santo Tomas, durante el 2017.

Objetivo: Comparar la resistencia de concretos comerciales de 21 y 28 MPA con el empleo de agregados pétreos del acopio Rodeb, con agregados tipo de un establecimiento reconocido a nivel nacional de la ciudad de Bogotá.

Metodología: El uso de agregados pétreos sin estándares de calidad, que garanticen las resistencias de concretos comerciales, es un problema en el país. Entender, que las propiedades físicas de los agregados pétreos, afectan las propiedades físicas del concreto fresco y de resistencia del endurecido.

En este estudio, se caracterizarán físicamente agregados pétreos de un centro de acopio "Rodeb" en Tocancipa empleados para la construcción de su Zona Franca y de agregados tipos soportados técnicamente en la ciudad Capital, para medir la variación mecánica en concretos de 21 y 28 Mpa. 
Resultados: se obtuvo que los agregados "acopio Rodeb" cumplen con los parámetros físicos que permite alcanzar las resistencias de diseño esperadas y en mayor grado que los resultados obtenidos por los agregados tipo.

Conclusión: Con este proyecto se busca generar conciencia sobre la variabilidad en las propiedades físicas y mecánicas de los concretos, según la caracterización de los agregados pétreos empleados.

Originalidad: Se busca implementar un diseño de mezcla en el acopio Rodeb para sus agregados

Limitaciones: Para continuar con la investigación, es necesario efectuar ensayos adicionales de caracterización fisico-quimico, para entender mejor como la textura y la forma de los agregados puede influenciar las propiedades mecanicas en los concretos. Adicionalmente y por otro lado es importante la divulgación de los resultados en la comunidad de Tocancipa

Palabras clave: agregados pétreos, concreto, gradación, resistencia, método Walker.

\section{Resumo}

Introdução: Este artigo é o produto da investigação "A influência dos agregados de pedra do estoque de Rodeb, nas propriedades mecânicas do concreto utilizado na construção da zona franca de Tocancipa", realizada na Universidade Santo Tomas, em 2017.

Objetivo: Comparar a resistência do concreto comercial de 21 e 28 MPA com o uso de agregados de pedra da pilha Rodeb, com agregados de tipo de estabelecimento reconhecido nacionalmente na cidade de Bogotá.

Metodologia: 0 uso de agregados de pedra sem padrões de qualidade, que garantam a resistência do concreto comercial, é um problema no país. Entenda que as propriedades físicas dos agregados de pedra afetam as propriedades físicas do concreto fresco e a resistência do concreto endurecido.

Neste estudo, serão caracterizados fisicamente agregados de pedra de um centro de coleta "Rodeb" em Tocancipa utilizado para a construção de sua Zona Franca e de agregados de tipo tecnicamente suportados na Capital, para medir a variação mecânica no concreto de 21 e $28 \mathrm{Mpa}$.

Resultados: foi obtido que os agregados "coleção Rodeb" atendem aos parâmetros físicos que permitem atingir a resistência esperada do projeto e em maior grau que os resultados obtidos pelos agregados do tipo.

Conclusão: Este projeto busca conscientizar a variabilidade nas propriedades físicas e mecânicas do concreto, de acordo com a caracterização dos agregados de pedra utilizados.

Originalidade: 0 objetivo é implementar um design de mix na coleção Rodeb para seus agregados.

Limitações: Para continuar com a investigação, é necessário realizar testes adicionais de caracterização físico-química, para entender melhor como a textura e a forma dos agregados podem influenciar as propriedades mecânicas do concreto. Além disso, por outro lado, é importante a divulgação de informações resultados na comunidade de Tocancipa.

Palavras-chave: agregados de pedra, concreto, gradação, resistência, método Walker. 


\section{INTRODUCTION}

Concrete is a mixture with certain proportions of crushed stone aggregates, water and cement; and it is the stone skeleton, generating better mechanical properties in the concrete when it is packed as densely as possible [1-4]. The characteristics of the mortar are those that define the stress that concrete can withstand as a composite material, and these characteristics are given by the mechanical and chemical properties of the aggregates used in the mixture.

The extraction of crushed stone materials can be classified as natural, artificial and industrial. For this project, the extraction of the crushed stone aggregate is located near natural deposits; in this case, the Robeb distribution center, stone material from Carmen de Carupa and Gachetá, townships of the Department of Cundinamarca, Colombia, where they are classified by their size and type.

As the aggregates exert a dynamic component in the mixture, it is necessary that they undergo a series of tests that indicate the mechanical behavior they will have when interacting physically and chemically with the cement, water and other crushed stone aggregates, varying the dosage of their quantities. That is why, in the present investigation, physical tests were carried out on the samples taken from the "Rodeb distribution center" stone aggregates and the "certified type" aggregates under Colombian Technical Regulations [5-9].

With results obtained in the laboratory and using the Walker Method, corresponding to an algorithmic procedure, the dosages are categorized as; the amount of fine aggregates, coarse aggregates, cement and water that must be used to reach a specific concrete strength. The cylinders failed after 28 days, confirming that the resistance obtained was equal to or greater than the design resistance.

The purpose of this research is to quantify the influence of crushed stone aggregates in commercial concrete mixtures by analyzing their physical properties, developing the designs of mixtures for 21 and $28 \mathrm{MPa}$ and analyzing the results obtained. As a study area, the free trade zone of Tocancipá has been selected, which is currently under construction, using concrete structures that incorporate the aggregates that are subject to analysis. Based on this paper, the community and especially the Tocancipá construction sector can have a reference point to evaluate and predict the durability and resistance of engineering structures.

\subsection{Literature Review and Research Background}

Many researchers have conducted studies focused on the analysis of the properties of concrete and the improvement of its main characteristics such as durability, 
workability and resistance, considering concrete as one of the most important materials in the development of a population. A large part of the characteristics of concrete, both in its plastic condition and in hardened condition, depend on the characteristics and properties of the aggregates [9], noting that one of the properties that influences the strength of the particle size is granulometry, and it is necessary that the gradation conforms to the specifications of already established granulometric curves that guarantee the greatest compaction of the mixture and adequate handling without causing segregation. It also indicates that the ideal shape of the particles is the rounded one, that the porosity should be as minimal as possible, that it should present a good resistance (since the failure of the concrete is governed by this characteristic) and that it must be able to withstand changes in environmental conditions.

An optimal concrete is obtained from an aggregate structure with the appropriate granulometry, so that the particles accommodate and the cement covers the interparticle spaces. Likewise, the workability of concrete is directly related to the absorption, shape, texture, size and granulometry of the aggregates, which in turn influence the adhesion between the matrix and the aggregates, modifying their resistance [2-3]. The strength of concrete depends on the structure of the grains of the particles, on the crushing and exploitation processes and on the resistance of the aggregates in general. This is why, prior to processing from mixtures, it is necessary to analyze the mechanical properties of toughness, adhesion, hardness and condition of the aggregates, guaranteeing the absence of detrimental substances, such as high clay content or organic matter [11].

Some researchers have tried to reduce the use of river sand for concrete mixtures, using crushed stone powder as a fine aggregate. This research resulted in an improvement in the mechanical properties of concrete. The above is proof of the importance of aggregates in the strength of concrete [12].

More recent studies determined that the strength of concrete is increased by using $9.5 \mathrm{~mm}$ aggregates -lower than those commonly used-and that the strength of concrete did not increase as the amount of cement increased beyond $850 \mathrm{~kg} / \mathrm{cm}^{2}$ [13].

On the other hand, some researchers have focused their studies on the development and analysis of the design methods of concrete mixtures, which help obtain the expected strengths by analyzing the properties of cement and aggregates. These determined the basic guidelines and preliminary information such as the average resistance required, settlement, the estimates of mixing water and the water / cement ratio according to the desired strength and durability characteristics. Similarly, the dose development was carried out under the methodologies of Füller and Walker [11]. In the twentieth century, four methods were established, ACl, Füller, Thompson, 
Bolomey and Faury, in order to provide a starting point for future studies related to the dosing of concrete mixtures, considering the increasingly demanding requirements of this material within the field of construction [15].

Finally, C. A. Campos, in order to further the properties of concrete, exposes the design of mixtures under three methodologies: $\mathrm{ACl}$, Walker and by the method of combining the fineness modules of aggregates [16].

\section{MATERIALS AND METHODS}

Bearing in mind that the objective of the research is to determine the behavior of the fine and coarse aggregates from the Rodeb distribution center, such as stone material used in concrete mixtures, the methodology is described below:

Firstly, sampling was carried out according to NTC 129 at the Rodeb distribution center [17]. The material corresponds to river sand and crushed stone, from Carmen de Carupa and Gachetá, municipalities annexed to the Department of Cundinamarca, which for the purpose of the investigation will be called "experimental aggregates". It is important to highlight that the maximum size of the coarse aggregate selected for the present research was set at $1 / 2$ "in diameter because it is a value that is within the ranges recommended by the structural technical standards. This maximum size achieves a suitable contact surface between the cement and the gravel, which increases the adhesion surface. In the same way, this maximum size is frequently used in constructions, both in columns and in beams, plates and some foundations.

Subsequently, its physical characterization is carried out by means of density, absorption, grain size and fineness modulation tests, following the Colombian Technical Standard (NTC) for each test.

Once the results of the tests are obtained, the mixing design is carried out, introducing two analysis variables, associated with the resistance of 21 and $28 \mathrm{MPa}$, used in the construction of the Tocancipá free trade zone and following the procedure established in the Walker method [16]. From this design, the concrete test tubes are prepared which will be subjected to the compression resistance test, using gray cement for general use from the Argos Company.

In order to have a reference point, the same procedure described above is performed with aggregates supplied by RODEO LTDA, called "certified aggregates" and which are marketed in Tocancipá; the above, in order to compare the results obtained with the experimental aggregates and determine their behavior in concrete mixtures. 


\section{Instruments and procedures.}

The tests for the physical characterization of the aggregates, the regulations under which they are developed, the processes performed and the instruments used, are described below.

\section{Fine aggregate density}

In accordance with the provisions of NTC 237 [3] "Test to determine the density and absorption of fine aggregates", the materials and equipment required are:

- Weighing machine

- Pycnometer

- Flask

- Conical mold

- Rammer

- Furnace

The procedure described in the standard establishes that to perform the test, it is necessary to dry the sample in the furnace and, at the moment when the material is manageable, immerse it in water for 24 hours. The water is then removed to spread the sample on a flat surface so that the particles dry until they reach the SSD (Saturated Surface Dry) condition.

A pycnometer is partially filled with water and 500 grams of the fine aggregate in the SSD condition is introduced. Subsequently the pycnometer is filled with a little more water and stirred. The air bubbles are removed and the total mass of the pycnometer, the mass of the sample and the water are determined. Once this value is obtained, the pycnometer material is extracted and allowed to dry at $110 \pm 5^{\circ} \mathrm{C}$ before being cooled at room temperature for 1 hour. The mass of the sample is obtained as well as the mass of the pycnometer filled with water at $23 \pm 2{ }^{\circ} \mathrm{C}$. With the above values, it is possible to determine the density and absorption of the material according to the equations established in the standard.

\section{Coarse aggregate density.}

According to NTC 176 - "Test to determine the density and absorption of coarse aggregate" [7], the necessary equipment is: 
- Weighing machine

- Metal baskets

- Water tank

- Suspension device

- $\quad$ Sifters

- Furnace

The procedure described in the standard is summarized by drying the sample in the furnace at a temperature of $110 \pm 5^{\circ} \mathrm{C}$. When it is at room temperature it is immersed in water for $24 \pm 4$ hours. The material is then taken by drying it lightly with a cloth to remove surface water, thus achieving the SSD condition. Once in this state its mass is determined. The sample is then immersed in water using the metal basket and the mass of the material in the water is determined. Finally, the sample is dried in the oven at $110 \pm 5^{\circ} \mathrm{C}$ and allowed to cool before its mass is determined. With the obtained values, the density and the absorption of the material are calculated.

\section{Granulometry and fineness modulus.}

The standard NTC 77 "Test for screening analysis of fine and coarse aggregates" [6], requires the following equipment:

- Scales

- $\quad$ Sifters

- Furnace

The standard states that a minimum of $300 \mathrm{~g}$ of fine aggregate and $2 \mathrm{~kg}$ of coarse aggregate should be taken for a maximum nominal size of $1 / 2$ "in.

The test is continued by selecting the group of sieves to be used to obtain the required information. The sieves are arranged in decreasing order and the sample is poured, shaking it to ensure that the aggregates are properly retained according to their size. Subsequently, the retained mass in each sieve is determined.

In order to determine the fineness modulus, the retained percentages accumulated in the sieves described in the standard are added, and divided by 100.

\section{Walker's Method}

Using the data obtained from the laboratory tests it was possible to obtain the design of the mixture for resistance of 21 and $28 \mathrm{MPa}$ following the method developed by 
American professor Stanton Walker, who considers within it, the profile of the aggregate (rounded or crushed), the maximum nominal size, the density of the cement and aggregates, the fineness modulus, the moisture content and the percentage of absorption of fine and coarse aggregates.

\section{Compression Strength Test.}

The compression strength test was carried out in accordance with NTC 673 - "Test of compression strength of concrete cylindrical specimens" [5], which contemplates the use of the following equipment and materials:

- Test machine.

- $\quad$ Steel load blocks, with which the test machine must be equipped.

- Load indicator

- Concrete specimens.

This test method consists of applying an axial compression load to the elaborated concrete cylinders, $150 \mathrm{~mm}$ in diameter and $300 \mathrm{~mm}$ high.

For this, the specimen to be tested is located on the lower support block of the test machine, verifying that the axles of the cylinder are aligned and that the load indicator is zero.

Then, the load is applied continuously by means of a hydraulic press, at a strength speed of $0.25 \mathrm{MPa} / \mathrm{s} \pm 0.05 \mathrm{MPa} / \mathrm{s}$. This compression load should be maintained until the load indicator shows a constant decrease in load and until the cylinder shows some well-defined type of fracture.

\section{RESULTS}

In order to measure the incidence of the Rodeb collection's aggregates in commercial concrete mixtures of 21 and $28 \mathrm{MPa}$ at 28 days, physical characterization tests were conducted. This is in order to prepare the concrete specimens that were subjected to mechanical tests of compressive strength.

This section will show the results of what was described above, comparing the two types of aggregates. 


\section{Tests for the physical characterization of aggregates}

For the physical characterization of the "experimental aggregates", the tests corresponding to density, absorption and granulometry were performed. Density indicates the amount of mass per unit volume that a body occupies. According to Standard NTC 385 "Terminology related to concrete and its aggregates" [18], the aggregate's density corresponds to the mass per unit volume occupied by the set of solid particles and the gaps between them [19].

Absorption is also a relevant parameter for the characterization of the aggregates, since it indicates the change in the mass of an aggregate due to the water absorbed in the spaces of the saturable pores when compared to the dry condition (Standard NTC 237) [3]. That is, it represents the increase in the mass of the aggregate due to the water that accumulates in the pores of the material, not including the water adhered to the outer surface of the particles [19, 20].

Another physical characteristic of the aggregates is determined by the granulometry test, which corresponds to the distribution of particle sizes of an aggregate (fine and coarse) by sieve analysis [6]. Through this test, it is possible to obtain the fineness modulus, which is a value that allows us to estimate how fine or coarse a material is [11].

The results of the physical characterization of the experimental and certified aggregates are presented below.

Table 1. Aggregate physical characterization tests

\begin{tabular}{lcc}
\hline & $\begin{array}{c}\text { EXPERIMENTAL } \\
\text { AGGREGATES RODEB }\end{array}$ & CERTIFIED AGGREGATES \\
\hline$\rho$ fine aggregate $(\mathrm{gr} / \mathrm{cm} 3)$ & 2,59 & 2,56 \\
\hline Absorption fine $(\%)$ & 0,44 & 0,41 \\
\hline$\rho$ coarse aggregate $(\mathrm{gr} / \mathrm{cm} 3)$ & 2,75 & 2,75 \\
\hline Absorption coarse $(\%)$ & 0,24 & 0,25 \\
\hline Tm (in) & $1 / 2$ & $1 / 2$ \\
\hline Fineness modulus & 2,78 & 2,91 \\
\hline
\end{tabular}

Source: own work

Granulometric curves identify the percentage of samples that pass through each sieve [6]. It and maximum aggregate size (MAS) for coarse stone materials affect the proportions of the mixture, as well as water and cement requirements. With regards to a concrete's workability, economy and durability, when the aggregates are very coarse, rigid mixtures can be produced that show poor workability; those aggregates 
that have a large deficiency or excess at some size and have a smooth granulometric curve will provide satisfactory results in the properties of fresh concrete.

According to NTC Standard 174 [8], it is possible to obtain the specifications of a granulometric curve for both fine and coarse aggregates [19]:
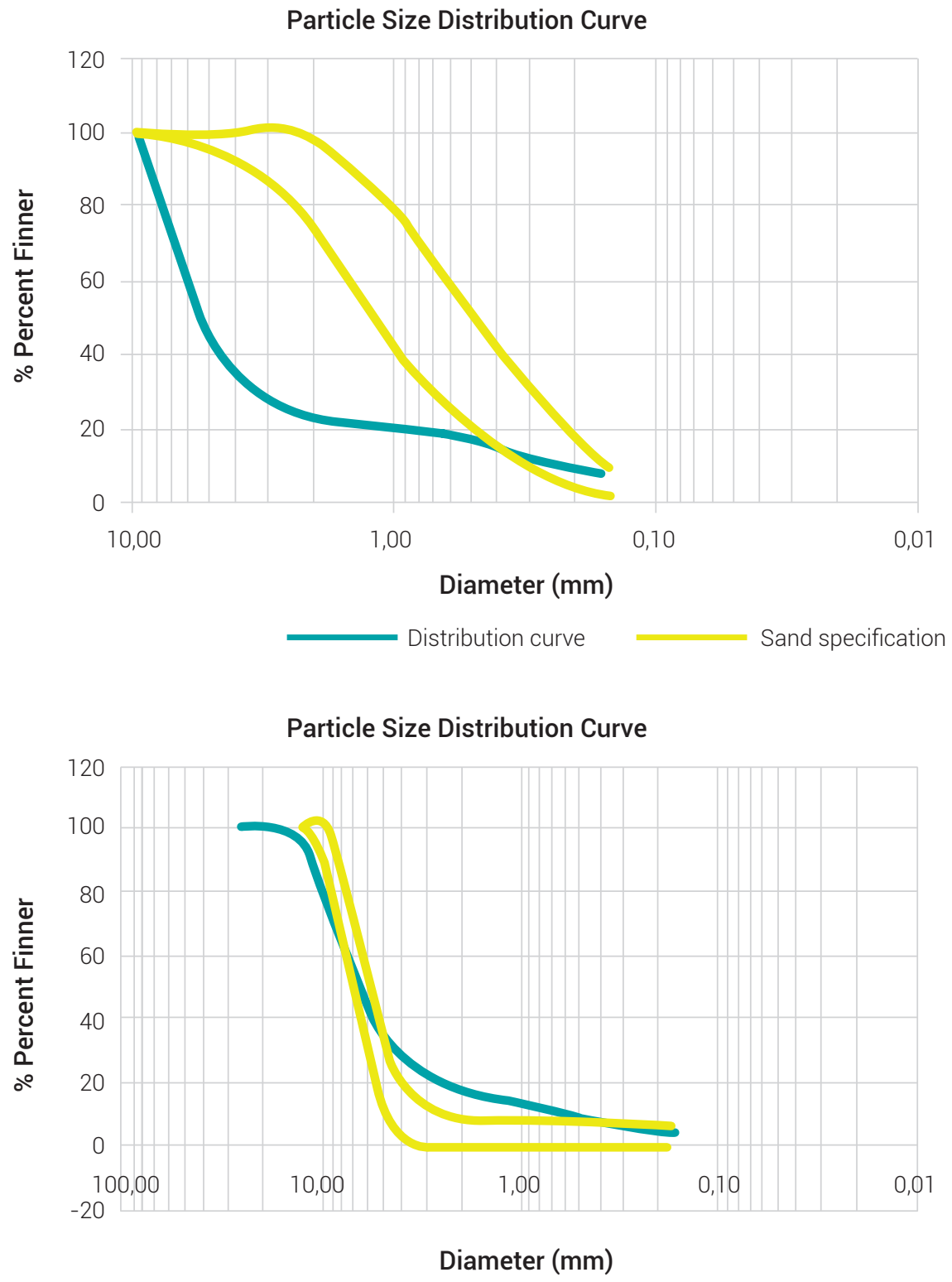

Distribution curve Gravel specification

Figure 1. Granulometric Curve Experimental Aggregate vs. Sand and Gravel Specifications

Source: own work 

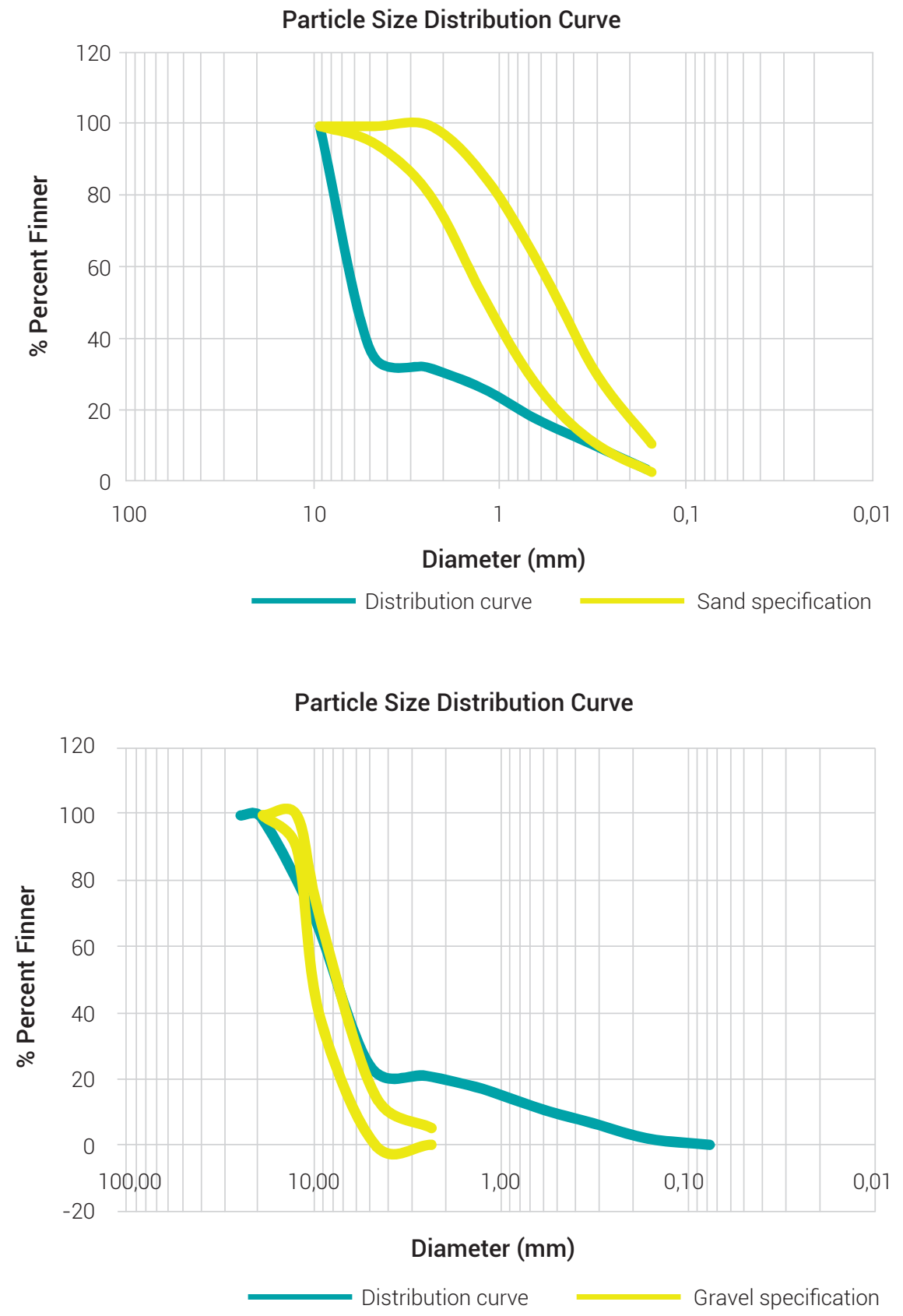

Figure 2. Granulometric Curve Certified Aggregate vs. Sand and gravel specifications Source: own work 


\section{Dosage of the mixture by the Walker method}

For the mixture's proportions, some parameters obtained from the physical characterization tests such as granulometric analysis, unit weight of the aggregates (fine and coarse), moisture content and percentage of absorption of the aggregates must be taken into account. Likewise, it is necessary to establish the variables with which the mixture will be designed as a settling choice (Slump), cement and water density and Average resistance $f^{\prime}{ }_{\text {cr }}{ }^{14}$ ] ] (For this study $f^{\prime}{ }_{\text {cr }}$ of 21 and 28 MPa were fixed), initial variables to be used for experimental and certified aggregates.

$$
\begin{aligned}
& \rho_{\text {cement }}=3.000 \mathrm{~kg} / \mathrm{m}^{3} \\
& \rho_{\text {water }}=1.000 \mathrm{~kg} / \mathrm{m}^{3}
\end{aligned}
$$

Settling $=3^{\prime \prime}$

The proportions from cement, aggregates and water for each average resistance and each type of aggregate (Experimental and Certified) are:

Table 2. Dosage of concrete mixtures of aggregates (Experimental and Certified

\begin{tabular}{|c|c|c|c|c|c|}
\hline \multicolumn{6}{|c|}{ DOSAGES OF CONCRETE MIXTURES } \\
\hline AGGREGATES & $\begin{array}{l}\text { "STRENGTH } \\
\text { (MPa)" }\end{array}$ & $\begin{array}{l}\text { "CEMENT } \\
(\mathrm{kg}) "\end{array}$ & $\begin{array}{l}\text { "FINE AGGREGATE } \\
(\mathrm{kg}) "\end{array}$ & $\begin{array}{c}\text { “COARSE } \\
\text { AGGREGATE (kg)" }\end{array}$ & $\begin{array}{l}\text { "WATER } \\
\text { (lt)" }\end{array}$ \\
\hline \multirow{4}{*}{ EXPERIMENTAL } & \multirow{2}{*}{21} & 315,8 & 759,91 & 1003,28 & 207 \\
\hline & & \multicolumn{4}{|c|}{$1: 2.41: 3.18$} \\
\hline & \multirow{2}{*}{28} & 373,7 & 776,09 & 933,21 & 207 \\
\hline & & \multicolumn{4}{|c|}{$1: 2.08: 2.50$} \\
\hline \multirow{4}{*}{ CERTIFIED } & \multirow{2}{*}{21} & 386,8 & 910,96 & 844,82 & 200 \\
\hline & & \multicolumn{4}{|c|}{$1: 2.35: 2.18$} \\
\hline & \multirow{2}{*}{28} & 352,9 & 979,48 & 836,94 & 187 \\
\hline & & \multicolumn{4}{|c|}{$1: 2.78: 2.37$} \\
\hline
\end{tabular}
aggregates).

Source: own work

The mixing water represents the amount of water that the cement requires per unit volume of concrete to generate a hydrated paste. That is to say, a plastic mixture of cement and water that obtains a new structure (cement gel); while hydration of the cement, with the necessary fluidity, facilitates the proper lubrication of the aggregates when the concrete is in a plastic state [11].

On the other hand, when this paste gradually stiffens to form a solid mass, this state of the concrete is known as setting and hardening. To complete the hydration 
of the cement, an amount of water with an approximate weight of $25 \%$ of cement is required, that is to say, a water - cement ratio of 0.25 is required. Generally, for normal concrete, the water - cement ratio varies from 0.40 to 0.60 [21].

The water - cement ratios that were obtained in the mixtures corresponding to each type of aggregate were:

Table 3. W / C ratio of concrete mixtures of experimental and certified aggregates.

\begin{tabular}{lcc}
\hline & ratio water-cement $(\%)$ & \\
\hline \multicolumn{1}{c}{ AGGREGATES } & $\mathbf{f c}^{{ }^{\prime}(\mathbf{M P a})}$ & $\mathbf{W} / \mathbf{C}$ \\
\hline \multirow{2}{*}{ EXPERIMENTAL } & 21 & 0,68 \\
\hline \multirow{2}{*}{ CERTIFIED } & 28 & 0,58 \\
\hline
\end{tabular}

Source: own work

\section{Test for compressive strength of concrete}

The compressive strength of concrete is defined as the ability to withstand an axial load per unit area of a concrete specimen. It is usually expressed in megapascals MPa (kilograms per square centimeters $\mathrm{kg} / \mathrm{cm}^{2}$ ) or in PSI (Pounds per square inch lb. / in ${ }^{2}$ ). This resistance can vary according to the concrete's age. It is estimated that the resistance at 7 days is usually $75 \%$ of the resistance at 28 days, and the resistance at 56 and 90 days is approximately 10\% and 15\% higher than resistance at 28 days [22-23].

This parameter is obtained by testing concrete cylinders in accordance with the procedure described in the standard "Compressive strength test of concrete cylindrical specimens", which consists of applying an axial compression load to molded cylinders or cores at a speed that is within a prescribed range until the fault occurs [6]. The standard procedure states that the concrete cylinder is required to be 28 days old to be tested [24].

To perform this test, a specific number of concrete cylinders were previously prepared for each type of aggregate, see Table (4). Taking into account that, according to statistical analysis, if a group of data follows a normal distribution for an average of $\mathrm{n}$ consecutive trials, it also follows a normal distribution with an equal coefficient of variation and standard deviation. However, when the number of results is less than 30 , the standard deviation values and coefficient of variation are not reliable enough [25]. 
Table 4. Minimum number of test tubes made for the compression strength test.

\begin{tabular}{lcc}
\hline & \multicolumn{2}{c}{ Number of test cylinders } \\
\hline \multicolumn{1}{c}{ Aggregates } & Strength $\mathbf{f}^{{ }^{\prime}} \mathbf{c}(\mathbf{M P a})$ & Number cylinders \\
\hline \multirow{2}{*}{ Experimental } & 21 & 30 cylinders \\
\hline \multirow{2}{*}{ Certified } & 28 & 30 cylinders \\
\cline { 2 - 3 } & 21 & 30 cylinders \\
\hline
\end{tabular}

Source: own work

Concrete curing is the process that is carried out after the concrete cylinders are made. It consists of maintaining both temperature and an adequate moisture content, for a period after the placement and finishing of the concrete, so that the concrete can develop the properties with which the mixture was designed [22, 24].

The structural design is generally based on concrete strength at 28 days, $70 \%$ of which is achieved at the end of the first week after concrete placement [21, 24].

Concrete cylinders designed with $21 \mathrm{MPa}$ and $28 \mathrm{MPa}$ resistors, made with experimental and certified aggregates, failed after 28 days and have the following compressive strengths: 


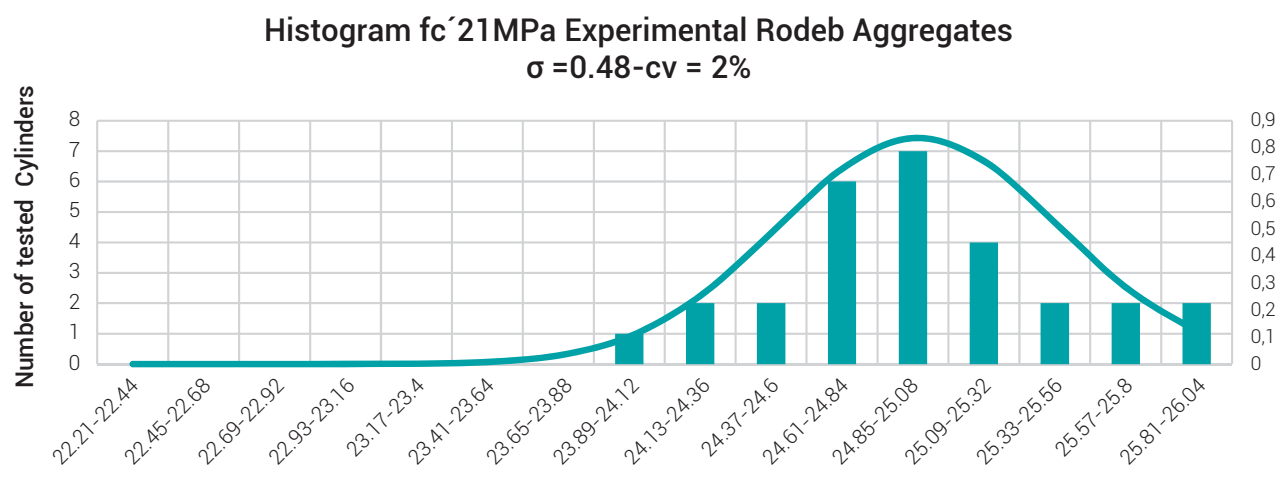

Compressive strength (MPa)

Histogram fc'21MPa Certified Aggregates $\sigma=0.66-\mathrm{cv}=2 \%$

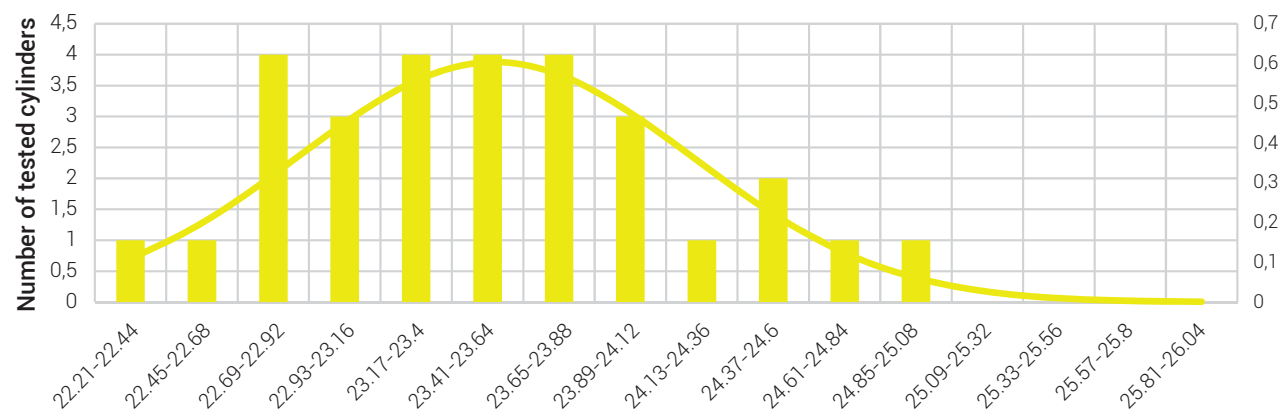

Compressive strength (MPa)

Histogram fc'21MPa Certified Aggregates vs. Experimental (Rodeb)

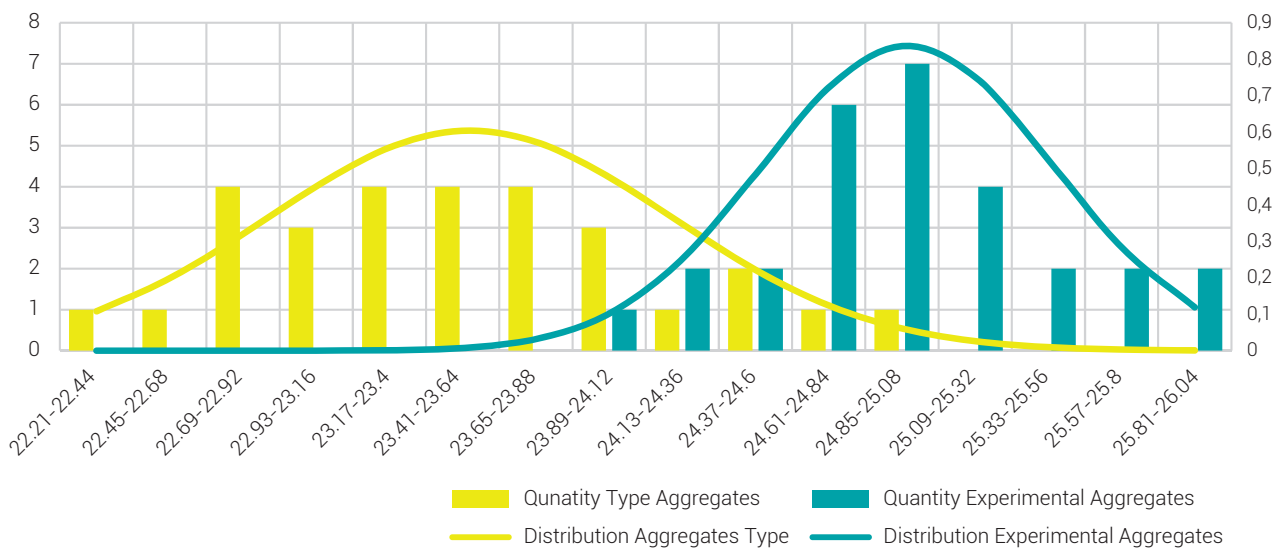

Figure 3. Scatter diagram of concrete cylinders from $21 \mathrm{MPa}$ at 28 days for experimental aggregates vs. certified aggregate

Source: own work 


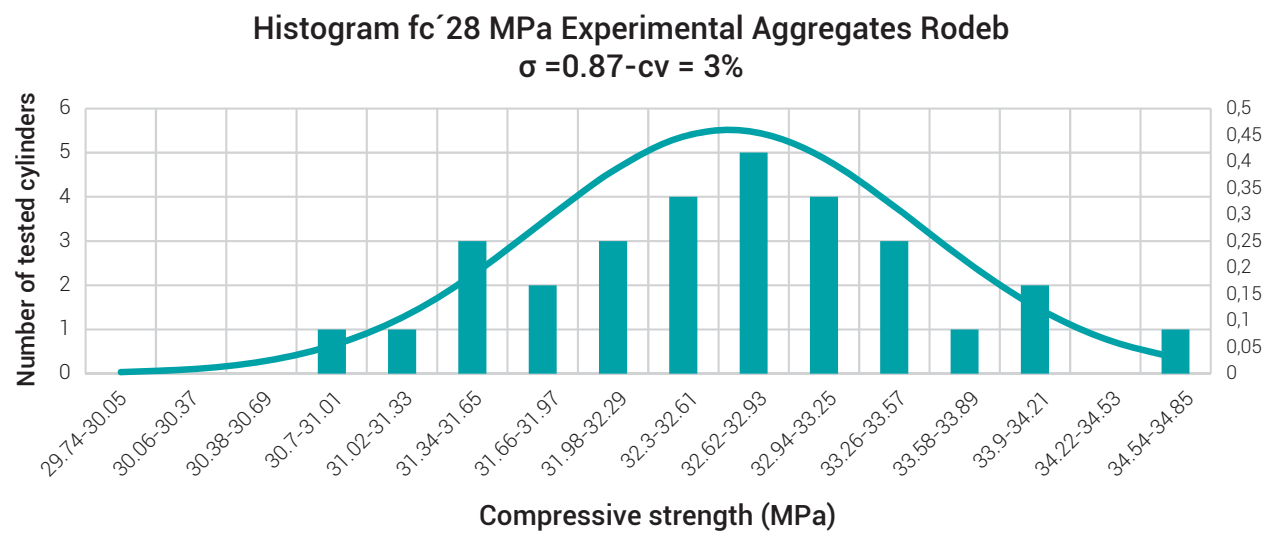

Histogram fc'28Mpa Certified Aggregates $\sigma=0.85-\mathrm{cv}=3 \%$

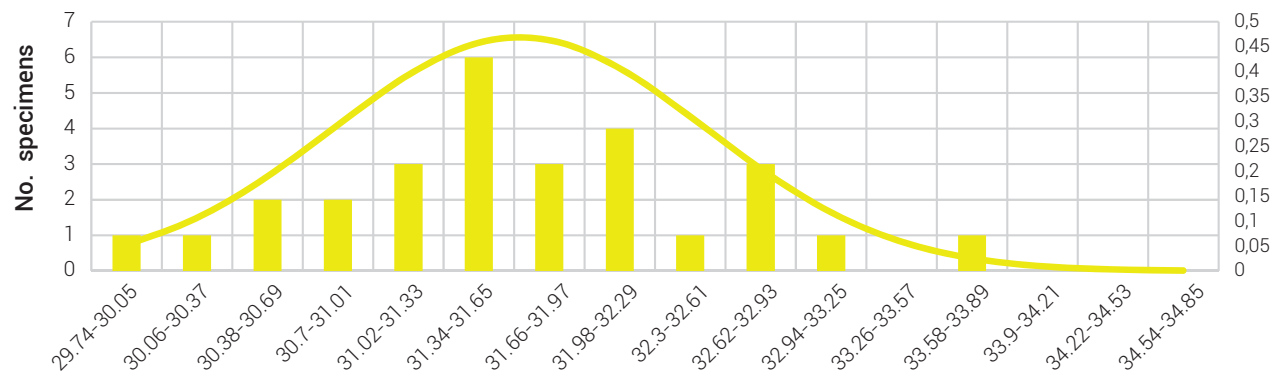

Compressive strength (MPa)

Histogram fc'28Mpa Certified Aggregate Vs Experimental (Rodeb)

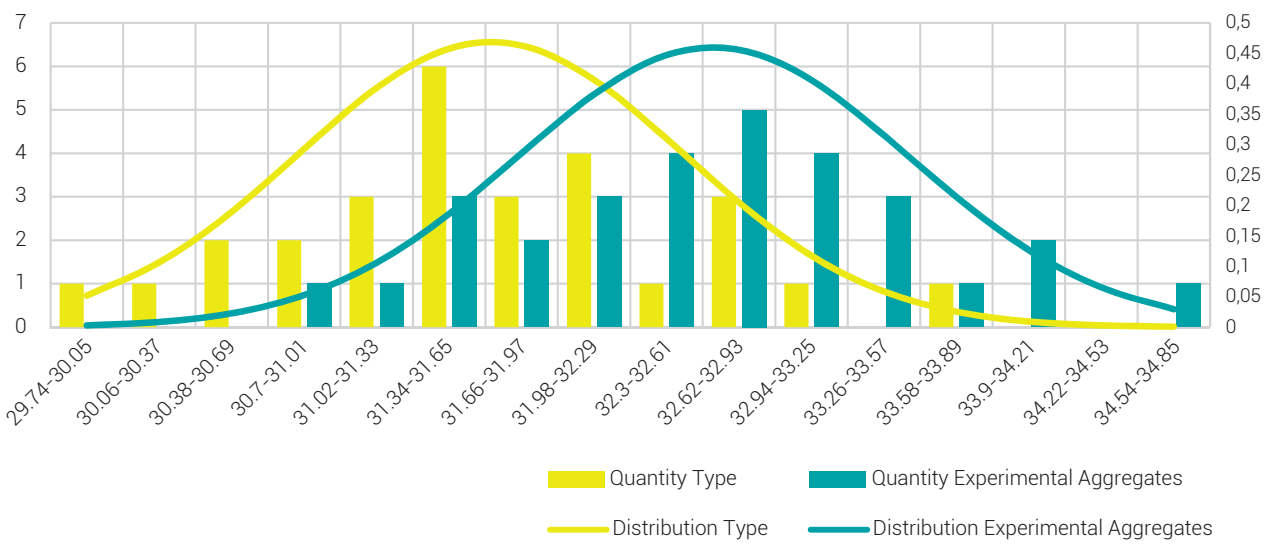

Figure 4. Dispersion diagrams of $28 \mathrm{MPa}$ concrete cylinders at 28 days for experimental aggregates (Rodeb) vs certified aggregates

Source: own work 


\section{DISCUSSION AND CONCLUSIONS}

According to the results obtained in the physical characterization laboratory tests, the aggregate's behavior on the properties of the concrete can be identified. With regards to the granulometric curve obtained from the testing of the granulometric sieve analysis, it is evident that the "Experimental Rodeb Collection" and "Certified" fine aggregates show a poor gradation in relation to the coarse aggregates that, although they do not fully meet the specifications established in NTC 174, they adjust to the granulometric curve of the standard. The lack of variety of sizes, or deficiency of one or more aggregate sizes per mesh, generate a reduction in the concrete's workability in its fresh state, its placement and finishing [22]. In addition, a poor gradation of the material may influence the dosage of the concrete, since the existing spaces between the aggregates can be increased and in this way, the amount of water and cement must be greater so that the mixture is manageable $[25,26]$.

On the other hand, absorption is a relevant factor in the design of concrete mixtures, since it determines the amount of water that the aggregate absorbs. The aggregate's absorption in a saturated state with dry surface SSD, varies between $0.2 \%$ and $2 \%$ for fine aggregates and between 0.2 and $4 \%$ for coarse aggregates [22]. The absorption values obtained for the experimental Rodeb and certified aggregates are between $0.41 \%$ and $0.44 \%$ for fine aggregates and between 0.24 to $0.25 \%$ for coarse aggregates; values that influence the concrete, developing greater manageability and resistance to freezing and thawing $[25,26]$.

Bulk density is defined as the aggregate weight that is required for a volume unit of concrete. The resulting density values for experimental Rodeb and certified aggregates are 2.56 and $2.59 \mathrm{~g} / \mathrm{cm}^{3}$ for fine aggregates and $2.75 \mathrm{~g} / \mathrm{cm}^{3}$ for coarse aggregates, which are within the usual values between $2.30 \mathrm{~g} / \mathrm{cm}^{3}$ and $2.8 \mathrm{~g} / \mathrm{cm}^{3}$ [12]. This characteristic turns out to be significant, since obtaining densities within the described range can directly influence the volumetric weight and compressive strength of concrete [2].

The maximum size obtained for the two types of aggregate is $1 / 2$ "in. This parameter is vital in the concrete's properties, which should not be greater than 1"in, since during the mixing; an increase in size can decrease the concrete's density, stiffness and strength $[25,28]$.

The fineness modulus is a value that allows us to estimate how fine or coarse a material is. Acceptable values are between 2.2 and 3.1 [2]. In relation to experimental aggregates, a modulus of fineness of 2.78 and 2.91 was obtained for certified aggregates, which are classified as medium fine and slightly coarse aggregates respectively [25]. These values indicate that lower amounts of cement and water are required to 
obtain adequate concrete strength and a lower likelihood of shrinkage cracking due to concrete drying [2].

When doing a visual analysis of the material under study, it was identified that it presented rounded shapes, which produce a greater adherence when compared to materials whose grains are less rounded. This generates a greater resistance to compressive stresses in the concrete in a percentage that varies between 10 and $20 \%$ when compared to concretes that use rounded aggregates [28].

In accordance with the proportions of the mixture, it was identified that in the case of "experimental aggregates Rodeb collection", a smaller amount of fine aggregate is required in relation to the "certified" aggregates. Smaller amounts of this type of aggregate represent a positive aspect in the concrete, considering that the granulometric analysis yielded negative data related to fine aggregates, taking into account that they do not adjust to the granulometric curve of the standard. In addition, these amounts decrease the cost of the aggregates that are required in the concrete mix. It should be noted that some researchers support the variation of resistance over time of concrete from weathering processes for fine aggregates. High levels of potassium, magnesium and calcium show an increase in the strength of concrete [27].

Regarding the water-cement W / C ratio, values of 0.68 and 0.58 were reached for resistances of $21 \mathrm{MPa}$ and $28 \mathrm{MPa}$ respectively. The value obtained for the resistance of $28 \mathrm{MPa}$ is within the W / C ratio range for normal concretes [21], and within the established range of 0.3 to 0.7 for the permeability of a cement paste kept continuously moist. However, low water-cement ratios are recommended as they improve the development of concrete strength whilst segregation and bleeding are reduced. They contribute to the tightness of concrete, and prevent saturation of most aggregates. They generate good quality pastes and produce concrete resistant to corrosion and exposure from acids and sulfates. On the other hand, water-cement ratios of less than 0.40 generate concrete resistant to external attacks, chlorides, sulfate and freezing-thawing [22].

It is identified that the described results of physical characterization and dosage of concrete influence the strength of the concrete. Taking into account that, when comparing the strengths of the mixtures alluding to each source of stone material, it was possible to demonstrate that the concrete specimens based on the "Rodeb collection experimental aggregates" present a dispersion of compressive strengths lower than the "certified aggregates". This is due to the quality of the preparation of the mixture. On the other hand, lower percentages of coefficients of variation indicate a better uniformity (quality) of the concrete, which is $2 \%$ for experimental aggregates 
and 3\% for certified aggregates; that is, they have excellent concrete uniformity since the coefficient of variation is within the acceptable range of $0 \%$ to $5 \%$ [25].

The correct characterization of the materials used in the construction from the Bogotá savannah is fundamental, since this allows for identifying the properties and aptitudes for specific uses, which leads to guaranteeing the durability and resistance in civil works. Specifically, the free zone of Tocancipá, Cundinamarca is under construction and the results obtained from this research project indicate that the materials extracted and stored at the Rodeb Collection Point, from Carmen de Carupa and Gachetá, are suitable as aggregates in concrete. This is because the strengths obtained at 28 days were higher than expected, so it is possible to establish that the aggregates have intrinsic characteristics that make them resistant to compressive stresses, such that the resistance of hydraulic concretes is directly related to aggregate resistance [11].

Finally, we can support the theory of other researchers who concluded that the properties of crushed stone aggregates can affect and/or limit the compressive strength, durability and structural performance of concrete. Microscopic imaging and spectrometry yield pertinent analyses on microscopic characteristics of concrete structure, shape index, size distribution and surface texture [28-30]. However, this research shows that the shape and texture of the aggregates not only affect the properties of the concrete, but that percentages of water absorption, densities, sizes and gradation are also key aspects in obtaining concrete with good resistance.

\section{REFERENCES}

[1] J. I. Mora, "Tejido óseo, una nueva alternativa en agregados para el concreto," Revista Ingeniería Solidaria, vol. 25, no.1, 2019. [Online]. doi: https://doi.org/10.16925/2357-6014.2019.01.07

[2] J.L. Chan, R. Solís and E.I. Moreno, Influencia de los agregados pétreos en las características del concreto, Mérida México: Universidad Autónoma de Yucatán, 2000. [Online]. Available: http://www.revista.ingenieria.uady.mx/volumen7/influencia.pdf

[3] T. Ozturan, C. Cecen, "Effect of coarse aggregate type on mechanical properties of concretes with different strength," Cement Concr. Res., vol. 27, no. 2, 1997. [Online]. doi: https://doi. org/10.1016/S0008-8846(97)00006-9 
[4] M. Ali, M. Maslehuddin, M. Shameem, M. Barry, "Thermal-resistant lightweight concrete with polyethylene beads as coarse aggregates,” Constr. Build. Mater., vol. 164, 2018. [Online]. doi: https://doi.org/10.1016/j.conbuildmat.2018.01.012

[5] ICONTEC, Método para determinar la densidad y la absorción del agregado fino. Normas Técnica Colombiana 237. Bogotá, Colombia: Instituto Colombiano de Normas Técnicas y Certificación, 2001.

[6] ICONTEC, Método de ensayo para el análisis por tamizado de los agregados finos y gruesos. Norma Técnica Colombiana 77. Bogotá, Colombia: Instituto Colombiano de Normas Técnicas y Certificación, 2007.

[7] ICONTEC, Ensayo de resistencia a la compresión de especimenes cilindricos de concreto. Norma Técnica Colombiana 673. Bogotá, Colombia: Instituto Colombiano de Normas Técnicas y Certificación, 2010.

[8] ICONTEC, Especificaciones de los agregados para concreto. Norma Técnica Colombiana 174. Bogotá, Colombia: Instituto Colombiano de Normas Técnicas y Certificación, n.d.

[9] ICONTEC, Método de ensayo para determinar la densidad y la absorción del agregado grueso. Norma Técnica Colombiana 176. Bogotá, Colombia: Instituto Colombiano de Normas Técnicas y Certificación, n.d.

[10] D. S. Guzman, Tecnologias del concreto y del mortero, Bogotá, Colombia: Bhandar Editores LTDA, 2001. [Online]. Available: https://books.google.com.co/books/about/TECNOLOGIA_ DEL_CONCRETO_Y_DEL_MORTERO.html?id=EWq-QPJhsRAC\&redir_esc=y

[11] L. Gutiérrez, El concreto y otros materiales para la construcción. Manizales Colombia: Universidad Nacional de Colombia, 2003. [Online]. Available: http://bdigital.unal.edu. co/6167/

[12] S. Rajput, "An Experimental study on Crushed Stone Dust as Fine Aggregate in Cement Concrete," Materialstoday PROCEEDINGS, vol 5, no. 9. [Online]. doi: https://doi.org/10.1016/j. matpr.2018.06.070

[13] R. Solis, E. I. Moreno and E. Arjona, "Resistencia de concreto con agregados de alta absorción y baja relación a/c," Revista de la Asociación Latinoamericana de Control de Calidad, Patología y Recuperación de la Construcción. [Online]. doi http://dx.doi.org/10.21041/ra.v2 i1.23 
[14] S. L. Huanca, Diseño de mezclas de concreto. Puno, Perú: Universidad Nacional del Antiplano, Facultad de Ingeniería Civil, 2006. [Online]. Available: https://itacanet.org/esp/construccion/ concreto/dise\%c3\%B10\%20de\%20mezclas.pdf

[15] O. Giraldo, Dosificación de mezclas de Hormigón. Medellín, Colombia: Universidad Nacional de Colombia, Facultad de minas, 2006. [Online]. Available: http://bdigital.unal.edu.co/ 43658/1/3352874.19946.pdf.pdf

[16] C. A. Huertas, Diseño de mezclas de concreto, Lima, Perú: Civilgeeks.com, Ingeniería y Construcción, 2013. [Online]. Available: https://civilgeeks.com/2014/03/26/apuntes-sobre -diseno-de-mezclas-de-concreto-ing-carlos-huerta/

[17] ICONTEC, Práctica para la toma de muestras de agregados. Normas Técnica Colombiana 129. Bogotá, Colombia: Instituto Colombiano de Normas Tecnicas y Certificación, 1995.

[18] ICONTEC, Terminología relativa al concreto y sus agregados. Norma Técnica Colombiana 385. Bogotá, Colombia: Instituto Colombiano de Normas Técnicas y Certificación, n.d.

[19] British Standards Institution, BS 882; Specification for Aggregates from Natural Sources for Concrete. UK: British Standards Institution, London, 1996. [Online]. Available: https://www.academia.edu/26939733/Specification_for_Aggregates_from_natural_sources_for_concrete_ COPYRIGHT_British_Standards_Institute_on_ERC_Specs_and_Standards_Licensed_by_ Information_Handling_Services_COPYRIGHT_British_Standards_Institute_on_ERC_Specs_ and_Standards_Licensed_by_Information_Handling_Services

[20] J. M. García and B. A. Hinojosa, Caracteristicas y propiedades del mortero a base de cemento cal arena-poliestileno, para ser utilizado en aplanado de muros de tabique de barro rojo reconocido de la región en cuanto al grado de termicidad que brinde en edificaciones de la zona Veracruz. Boyacá del Rio - Medellín. Boca del Río, México: Universidad Veracruzana, Facultad de Ingenieria Civil, 2011. [Online]. Available: https://studylib.es/doc/7958947/\%E2\%80\%9Ccaracter\%C3\%ADsticas-y-propiedades-del-mortero-a-base-de-cemento

[21] A. H. Nilson, G. Winter, L.C. Urquhart and O.R. Charles, Diseño de estructuras de concreto. Ciudad de México, México: McGraw-Hill, 1999. [Online]. Available: https://www.u-cursos.cl/ usuario/7c1c0bd54f14c0722cefcofa25ea186d/mi_blog/r/32988036-Nilson-Diseno-De-Estructuras-De-Concreto_(1).pdf

[22] S. H. Kosmatka, B. Kerkhoff, W.C. Panarese and J. Tanesi, Diseño y control de mezclas de concreto. Skokie, Illinois, EE.UU: Portland Cement, 2004. [Online]. Available: https://issuu.com/ daniel0252/docs/dise__o_y_control_de_mezclas_de_con 
[23] A. Ajao, B. Ogunbayo, K. Ogundipe, O. Joshua, O. Olofinnade, "Experimental datasets on properties of river sand as an aggregate in replacement of crushed rock for interlocking stones production," Data in Brief., vol. 20. [Online]. doi: https://doi.org/10.1016/j.dib.2018.08.056.

[24] T. E. Harmsen, Diseño de estructuras de concreto armado. Lima, Perú: Fondo Editorial de la Pontificia Universidad Católica del Perú, 2005. [Online]. Available: https://es.slideshare.net/ FREDHYRONALDPABLO/diseno-de-estructuras-de-concreto-harmsen-r

[25] G.A. Rivera, Concreto Simple. Popayan, Colombia: Universidad del Cauca, 2013. [Online]. Available: https://www.studocu.com/es/document/universidad-nacional-de-san-agustin-de -arequipa/quimica/practica/tecnologia-concreto-y-mortero-rivera/2126289/view

[26] M. Wakchaure, A. Shaikh and B. Gite, "Effect of Types of Fine Aggregate on Mechanical Properties of Cement Concrete," International Journal of Modern Engineering Research, vol. 2, no. 5, 2012. [Online]. doi: http://citeseerx.ist.psu.edu/viewdoc/download?doi=10.1. $1.416 .8087 \&$ rep $=$ rep $1 \&$ type $=p d f$

[27] R. Hakon, H. Viggo, "Geochemical properties of aggregates - Concrete Quality," Bulletin of the International Association of Engineering Geology, vol 30, no. 1. [Online]. doi: https://doi. org/10.1007/BF02600689

[28] k. Güçlüer, "Investigation of the effects of aggregate textural properties on compressive strength (CS) and ultrasonic pulse velocity (UPV) of concrete," Building Engineering, vol. 27, 2020. [Online]. doi: https://doi.org/10.1016/j.jobe.2019.100949

[29] S Reddy, S. Deb, N. Mitra, R. Muppireddy, S. Kusam, "Influence of aggregate size on flexural fatigue response of concrete," Construction and Building Materials, vol. 229, 2019. [Online]. doi: https://doi.org/10.1016/j.conbuildmat.2019.116922

[30] F. Yu, D. Sun, J. Wang, M. Hu, "Influence of aggregate size on compressive strength of pervious concrete," Construction and Building Materials, vol. 209. [Online]. doi: https://doi.org/10.1016/j.conbuildmat.2019.03.140 